\title{
The Concept of Wastes to Energy Using Sugary Wastes
}

Fiza Sarwar, Wajeeha Malik, Muhammad

Salman Ahmed, and Harja Shahid

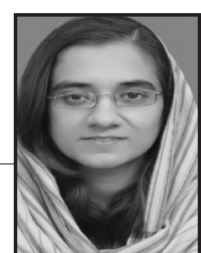

Fiza Sarwar

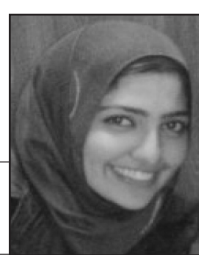

Wajeeha M.

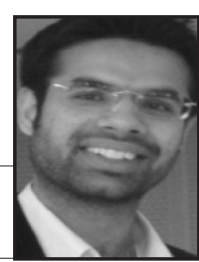

M. Salman A.

Abstract: This study was designed using actual effluent from the sugary mills in an Up-flow Anaerobic Sludge Blanket (UASB) Reactor to evaluate treatability performance. The reactor was started-up in step-wise loading rates beginning from $0.05 \mathrm{~kg}$ carbon oxygen demand (COD) $/ \mathrm{m}^{3}$-day to $3.50 \mathrm{~kg}-\mathrm{COD} / \mathrm{m}^{3}$-day. The hydraulic retention time (HRT) was slowly decreased from $96 \mathrm{hrs}$ to eight hrs. It was observed that the removal efficiency of COD of more than $73 \%$ can be easily achieved at an HRT of more than 16 hours corresponding to an average organic loading rate (OLR) of $3.0 \mathrm{~kg}-\mathrm{COD} / \mathrm{m}^{3}$-day, at neutral $\mathrm{pH}$ and constant temperature of $29^{\circ} \mathrm{C}$. The average VFAs (volatile fatty acids) and biogas production was observed as $560 \mathrm{mg} / \mathrm{L}$ and $1.6 \mathrm{~L} / \mathrm{g}-\mathrm{COD}_{\mathrm{rem}}-\mathrm{d}$, respectively. The average methane composition was estimated as $62 \%$. The results of this study suggest that the treatment of sugar mills effluent with the anaerobic technology seems to be more reliable, effective and economical.

Key words: Anaerobic digestion, sugary wastes, carbon oxygen demand, biogas, Pakistan

\section{Introduction}

Pakistan is a water deficient country; the quantity of available water resources has been declining day by day. In 1960 it was $5654 \mathrm{~m}^{3} /$ capita, by 2000 it was $1400 \mathrm{~m}^{3} /$ capita and by 2010 the capacity was expected to be $1000 \mathrm{~m}^{3} /$ capita (Ali, Hashmi et al 2009). The water quantity (flow rate) is decreasing day by day due to such factors as temperature, atmospheric pressure, wastage due to improper management, and pollution.

The available water in Pakistan is being polluted at an alarming rate, mainly due to untreated domestic and industrial effluents and agricultural/surface runoffs, etc. Domestic effluent includes sewage as well as sludge while industrial effluents only include waste sewage. The runoffs may include garbage and sediments. Due to all these effects of pollution, the only clean and potable water available is $18 \%$ and the remaining $82 \%$ is unfit for drinking purpose.

Besides water deficiency it is a known fact that Pakistan is deficient in energy, though it has a substantial potential of energy. The energy is not confined only to electrical energy, but bio-gas has also a significant share in this sector. However, bio-gas has not been given the attention it deserves. Biomass is an important resource in Pakistan, about $37 \%$ of total primary energy supply. The growing acceptance of anaerobic digestion at a simple, low-cost high rate and effective waste treatment technology make it a viable solution for pollution control, in addition to give support to energy resources sector.

The sugar industry plays an important role in the nation's economy. Progress in technology has been made by this industry. At the time of the Independence there were only two sugar mills, one at Rahwali in the Punjab and the other at Takhat Bai in the Khyber Pakhtun Khwa (KPK). The total quantity of sugar produced during 194748 was 7,932 tons. Today there are 75 sugar mills all over the country. The majority of these mills are based on sugar cane. The total crushing capacity of this industry is approximately 3.0 million tons per day.

By comparison, only four mills process beets for sugar production.

Molasses is a byproduct of the sugar manufacturing process and is exported to other countries. In Pakistan seven sugar mills convert a part of their molasses into industrial alcohol.

Pakistani sugar mills rarely exploit the possibilities of reusing wastes in the process, or as by-products. A considerable development of sucrochemistry and ethanol applications is expected in the near future. This development will bring forth problems to a scale (especially associated with pollution by aggressive molasses and vinasses) that makes the current problem appear insignificant (Pak-EPA 1999).

In order to secure the environment from the adverse impacts of untreated industrial effluent, it is necessary that all the waste water be treated as an integral part of their production before discharging the wastes into the receiving streams or rivers. Because Pakistan is facing an acute shortage of energy it is encouraging the technologies like UASB (Up-flow Anaerobic Sludge Blanket) Reactor technology will not only prevent water pollution but can help tackle the problem of the energy crises to a certain extent. For the treatment of sugar mills effluent the anaerobic technology seems to be reliable, effective and economical. Hence, a long-term comprehensive study is required to investigate the treatment feasibility of sugary wastes in a single-stage UASB reactor.

The main objectives of this study are to evaluate the treatability performance of sugary wastes usage under anaerobic conditions and to estimate the amount of bio- 
gas production from sugary wastes using a UASB reactor.

\section{Materials and Methodology Experimental UASB reactor}

Due to the advantages and high application potential of the UASB reactor for developing countries, it was decided to employ a UASB reactor for this study. A UASB reactor made up of acryl resin material with a total effective volume of 8.0 liters was used. It consisted of a reaction portion of 6.2 liters and a settling tank portion of 1.8 liters. The internal diameter of the reactor was eight centimeters and the thickness of the water jacket was 1.5 centimeters. The reactor had a water jacket to maintain a constant temperature of $29 \pm 0.50 \mathrm{C}$. The reactor was also equipped with a gas solid separator (GSS) and a mixer (Ali and Hashmi 2010). The systematic diagram of the UASB reactor is shown in the Figure 1.

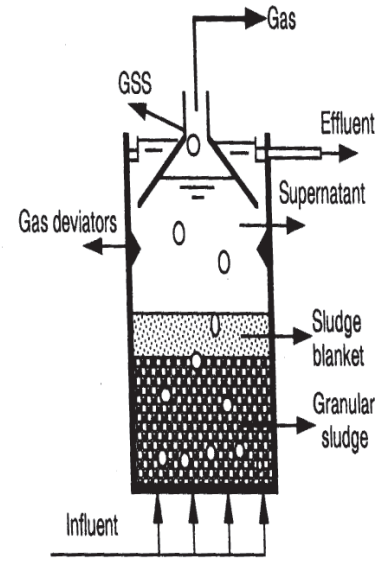

Figure 1 : UASB Reactor

\section{Substrate and Nutrients}

Actual domestic sewage was used as the sole carbon source in the feed (influent). Nitrogen and phosphorous were added in the form of $\left(\mathrm{NH}_{4}\right)_{2} \mathrm{SO}_{4}$ and $\mathrm{KH}_{2} \mathrm{PO}_{4}$ in accordance with the carbon oxygen demand (COD):N:P ratio of 550:5:1. Trace nutrients were added at a concentration of 1.o milliliter/liter after making a stock solution of nutrients in the following concentration, as shown in Table 1.

Table 1. Trace Nutrient Concentrations

\begin{tabular}{|c|c|}
\hline Trace Nutrient & Concentration $(\mathrm{mg} / \mathrm{L})$ \\
\hline $\mathrm{FeCl}_{3} \cdot 6 \mathrm{H} 2 \mathrm{O}$ & 5.2 \\
\hline $\mathrm{CoCl}_{2} \cdot 6 \mathrm{H}_{2} \mathrm{O}$ & 0.35 \\
\hline $\mathrm{ZnSO}_{4}$ & 0.28 \\
\hline $\mathrm{CaCl}_{2} \cdot 2 \mathrm{H}_{2} \mathrm{O}$ & 0.31 \\
\hline $\mathrm{CuSO}_{4}$ & 0.86 \\
\hline
\end{tabular}

\section{Seed Sludge}

Seventy percent of the UASB reactor was seeded with an anaerobic digester and activated sludge from the nearby waste water treatment plant. The characteristics of the seeded sludge under the startup condition of the reactor are shown in Table 2. The acclimatization process continued for about two to three weeks in the laboratory. The seed sludge provided 42 grams of volatile suspended solids (VSS). The loading rate was increased stepwise in order to avoid organic loading shocks. Hydraulic retention time (HRT) was also studied. Mixing was done twice a day.

Table 2. Characteristics of Seeded Sludge

\begin{tabular}{|c|c|}
\hline Parameters & Value \\
\hline Total Solids, TS (mg/L) & 74.80 \\
\hline Total Suspended Solids, TSS (mg/L) & 51.66 \\
\hline Volatile Suspended Solids, TVS (mg/L) & 39.80 \\
\hline Color & Blackish \\
\hline
\end{tabular}

\section{Operational Conditions}

The reactor was started-up in step-wise loading rates starting from $0.05 \mathrm{~kg}-\mathrm{COD} / \mathrm{m}^{3}$-day to $3.50 \mathrm{~kg}-\mathrm{COD} / \mathrm{m}^{3}$ day. The HRT was slowly decreased from 96 to 08 hours at constant neutral $\mathrm{pH}$ and mesophilic temperature.

\section{Monitoring and analysis}

$\mathrm{pH}$, temperature, influent and effluent COD, VFAs and gas production were monitored regularly, twice a week. Gas was collected over a tap water saturated with $\mathrm{NaCl}$. All analyses were carried out according to standard methods (APHA/AWWA/WEF 2005).

\section{Results and Discussion}

During the study the COD removal efficiency and the gas production was observed for various organic loading rate (OLR) and HRT at constant temperature and $\mathrm{pH}$.

\section{Start-Up of the reactor}

$\mathrm{pH}$ is the most important and principle operational parameter of anaerobic digestion. An optimum $\mathrm{pH}$ of " 5.5 to 6.0" was reported for the process of anaerobic digestion in UASB (Lettinga, Velsen et al 1980). Since the methanolic bacteria are highly sensitive to $\mathrm{pH}$ and require neutral $\mathrm{pH}$ conditions, this range seems to be unsuitable for the optimum growth of this kind of bacteria (Bhatti 1995). It was concluded that 7.8 is the optimum $\mathrm{pH}$, with no activity occurring below $\mathrm{pH}$ 6.8. These results suggest that optimum $\mathrm{pH}$ should lie within neutral condition $\mathrm{pH}$. This concept is also supported by Bhatti (1995).

Therefore, in our study we tried to maintain the $\mathrm{pH}$ of the reactor near to neutral by adding an external buffer in the form of $\mathrm{NaHCO}_{3}$ to the feed solution. The course of reactor $\mathrm{pH}$ during the experimental period, the effect of reactor $\mathrm{pH}$ on COD removal efficiency of the UASB, the formation of VAFs in the effluent, and the amount of biogas production are shown in the Figures 2 to 5 .

The $\mathrm{pH}$ of the reactor was highly alkaline; i.e., 8.7; but became acidic after two to three weeks of operation, and varied from 5.9 to 6.5 . It was later controlled at around 
neutral $\mathrm{pH}$ after the seventh day by the addition of $6 \mathrm{oml}$ of $0.5 \mathrm{M}$ (Mole) $\mathrm{NaHCO}_{3}$ per liter of the feed solution. During the neutral $\mathrm{pH}$ phase, high bicarbonate alkalinity of more than $1500 \mathrm{mg}-\mathrm{CaCO}_{3} / \mathrm{L}$ was observed, and that was initially less than $200 \mathrm{mg}-\mathrm{CaCO}_{3} / \mathrm{L}$ when there was no addition of external buffering in the form of $\mathrm{NaHCO}_{3}$.

The effect of $\mathrm{pH}$ on the COD removal efficiency shows that about $70 \%$ of the COD can be removed, if the $\mathrm{pH}$ of the reactor is kept neutral. Thus, by keeping the $\mathrm{pH}$ of the reactor at about 7.0, the effluent COD can be easily dropped down to the limits set by Pak-EPA NEQS (National Environmental Quality Standards). VFAs are one of the important parameter that shows the inefficiency of the reactor to convert acetic acid into methane.

In this study, the formation of VFAs was observed to be $560 \mathrm{mg} / \mathrm{L}$ (average value of the study). The maximum formation of VFAs $(68 \mathrm{omg} / \mathrm{L})$ was observed when the $\mathrm{pH}$ of the reactor was about 6.3. Corresponding to this $\mathrm{pH}$ only $49 \%$ of the COD was observed to be removed.

\section{Treatability Performance of the Reactor}

The treatment COD removal efficiency of the UASB was observed to be greatly dependent on HRT and OLR, at

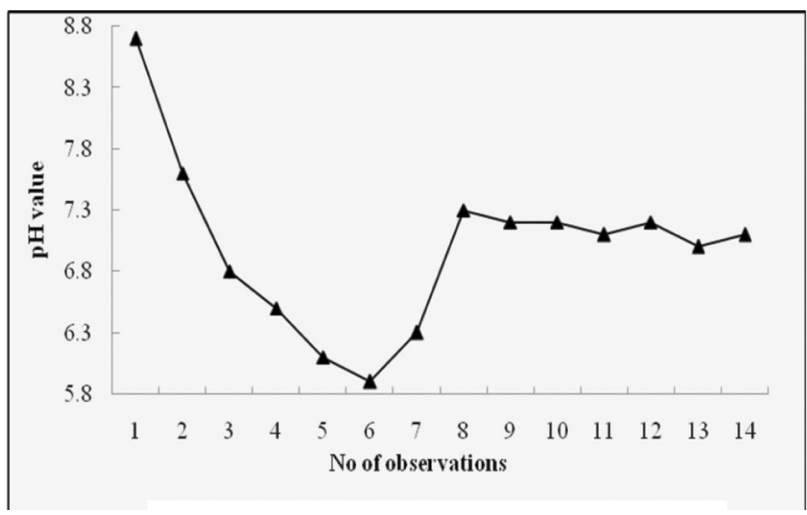

Figure 2. Time Course of $\mathrm{pH}$ During the Study Period

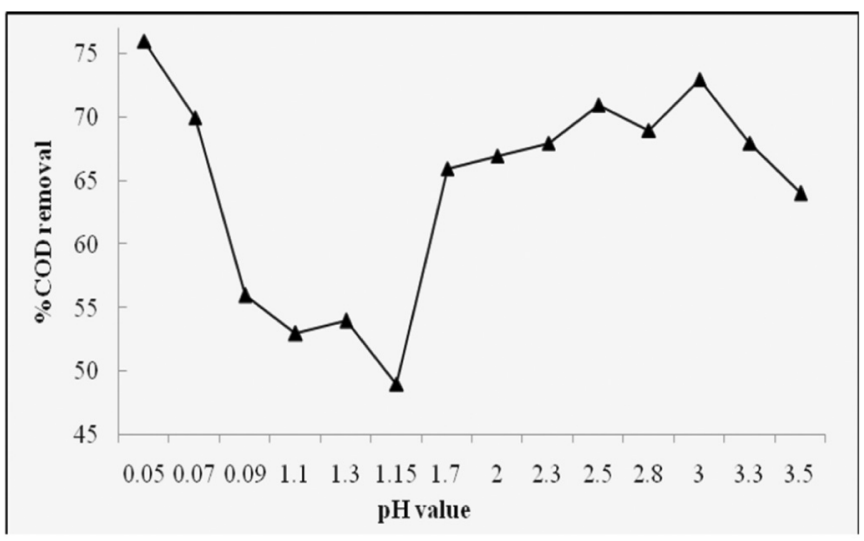

Figure 3. Effects of $\mathrm{pH}$ on COD Removel Efficiency

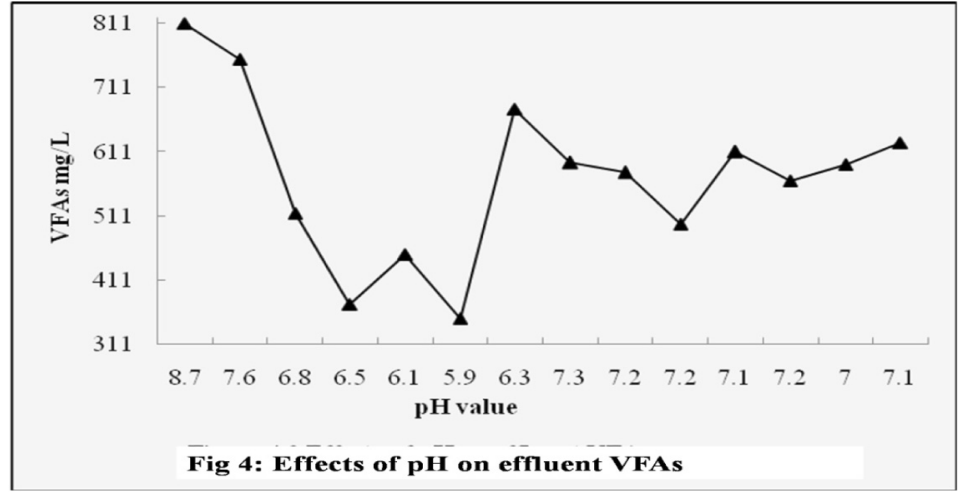

Figure 4. Effects of $\mathrm{pH}$ on Effluent VFAs

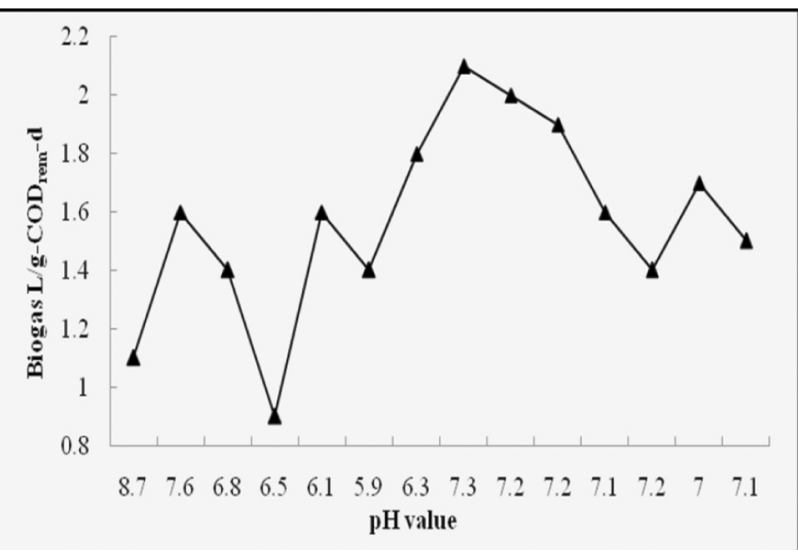

Figure 5. Effects of $\mathrm{pH}$ on Biogas Production

constant $\mathrm{pH}$ and temperature. The effects of OLR and HRT on the COD removal efficiency are shown in the Figures 6 and 7. The longer retention time seems to be more favorable in terms of COD reduction.

During an earlier stage of the experiment, when the HRT was high, the COD reduction was observed to be more than $76 \%$. At the sixth week the COD observed was the least, about $48 \%$ at an average HRT of 56 hours, due to the excessive accumulation of VFAs in the system and drop of $\mathrm{pH}$ to 5.9. The maximum COD (73\%) was observed in the twelfth week, when the average HRT was 16 hours and the OLR was observed to be 3.okg-COD/ $\mathrm{m}^{3}$-day, and the $\mathrm{pH}$ of the reactor was about 7.2. This indicates that $\mathrm{pH}$ greatly influences the performance of UASB reactor.

The removal efficiencies of total carbon oxygen demand COD achieved are in the range of 51 to $74 \%$ (Vieira 1988; Schellinkhout 1993; Seghezzo, Zeeman et al 1998). The reactors are operated at ambient temperatures (18 to $32^{\circ} \mathrm{C}$ ) and OLRs in the range of 0.9 to $3.55 \mathrm{~kg}-\mathrm{COD} / \mathrm{m}^{3-}$ day. The study shows a close resemblance in the results; i.e., the average COD removal was observed to be $69 \%$ at an average temperature of $290 \mathrm{C}$ and an average OLR of $2.5 \mathrm{~kg}-\mathrm{COD} / \mathrm{m}^{3}$-day. 


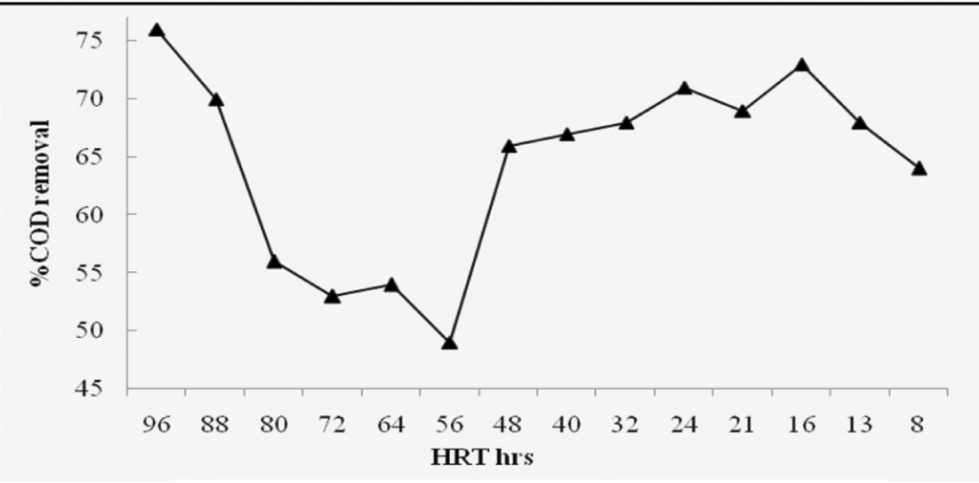

Figure 6. Effects of $\mathrm{pH}$ on Biogas Production

It was observed that for every step there was an increase in the COD removal efficiency of the reactor after establishing steady state conditions under a given OLR. And in every step of increasing the OLR, it was observed that there was an abrupt decrease in the COD removal efficiency due to the increase in concentration of VFAs in the reactor and heavy organic shocks.

The low peaks of efficiency observed during the sixth week in the beginning could be attributed to the variation in flow and acclimatization of seed sludge to the waste. For fulfilling the requirement of Pakistan's NEQS, the removal efficiency of COD of more than $73 \%$ can be easily achieved at an HRT of more than 16 hours and an average OLR of 3.okg-COD $/ \mathrm{m}^{3}$-day, and maintaining the $\mathrm{pH}$ and temperature of 7.2 and $290 \mathrm{C}$, respectively.

\section{Biogas Production in the Reactor}

Small gas bubbles were observed from the start of the experiment. The gas was collected in a smaller system saturated with $\mathrm{NaCl}$ solution. However, because of low gas pressure the gas production rates and deficiency in

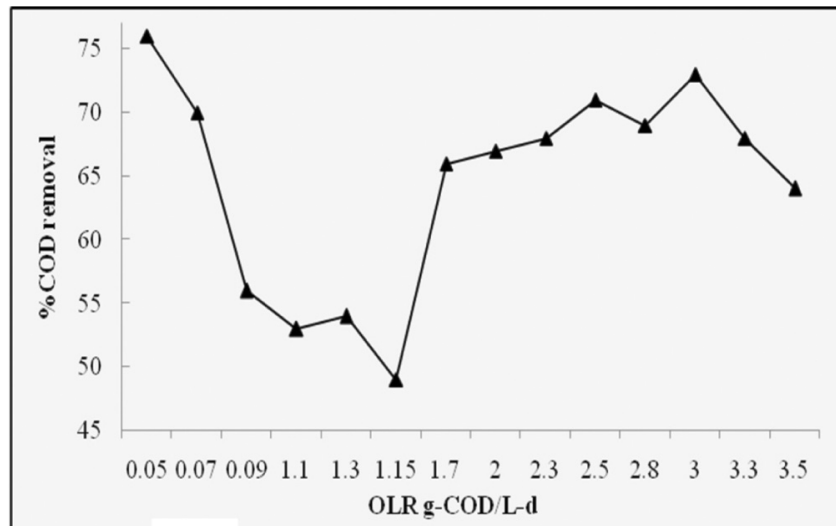

Figure 7. Effects of OLR on COD Removal Efficiency

the gas collection system, appreciable amounts of gas could not be collected until the second week. Methane ( $\left.\mathrm{CH}_{4}\right)$ content of 75 to $80 \%$ of the gas is reported by Bhatti (1995) and a study on dairy waste has shown it to be $75 \%$. The rest of the gas content will be mainly $\mathrm{CO} 2$, because these two gases are produced in the anaerobic digestion process. A portion of the gas could be $\mathrm{H} 2$, if the system is not working properly due to the presence of hydrogen-producing acetogens, which provide unfavorable conditions for the conversion of VFAs to acetate then to methane. The results of the study are shown below in Figure 8.

The low gas production of $0.85 \mathrm{~L} / \mathrm{g}$-CODrem-d was observed on the fourth day when the concentration of VFAs was found to be about $621 \mathrm{mg} / \mathrm{L}$. This indicates that the population of methanogenic bacteria had not grown appreciably and that facultative microbes may be competing for the sub-

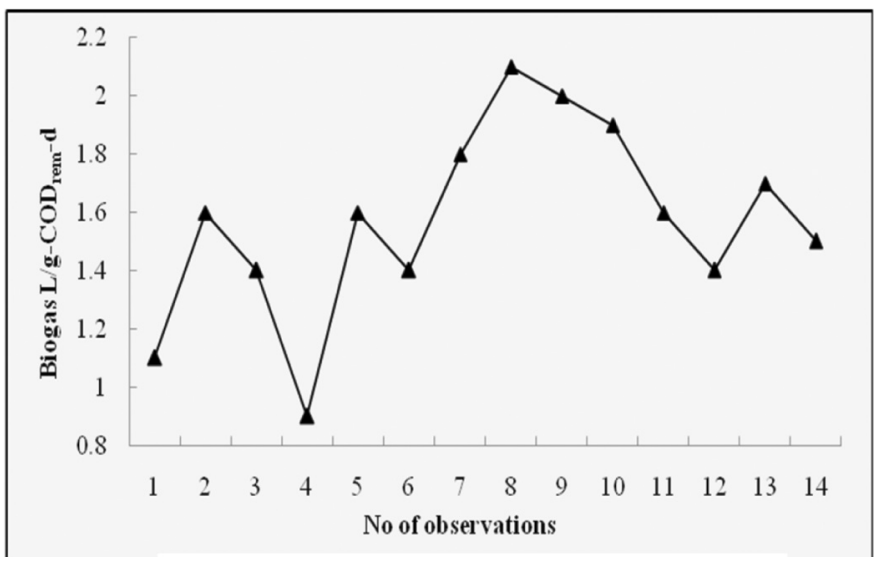

Figure 8. Time Course of Biogas Production

strate with the methane producing organisms.

An average gas conversation rate was calculated to be $1.6 \mathrm{~L} / \mathrm{g}$-CODrem-d, whereas, the estimated percentage concentration of methane and carbon dioxide was observed as $62 \%$ and $37 \%$, respectively.

Table 3. Observations and Calculations

\begin{tabular}{|l|c|}
\hline Flow rate, $\mathrm{m}^{3} / \mathrm{hr}$ & 210 \\
\hline Chemical Oxygen Demand, mg/L & 2850 \\
\hline Biochemical Oxygen Demand, mg/L & 2050 \\
\hline Total Suspended Solids, mg/L & 760 \\
\hline Total Volatile Suspended Solids, mg/L & 580 \\
\hline Velocity $\mathrm{m} / \mathrm{hr}$ & 0.5 \\
\hline Depth, $\mathrm{m}$ & 5.0 \\
\hline
\end{tabular}

Table 4. Reactors Configurations

\begin{tabular}{|l|l|}
\hline Dimensions, Dia $\times \mathrm{H}$ & $24 \mathrm{~m} \times 5 \mathrm{~m}$ \\
\hline Hydraulic Retention Time, HRT & $16 \mathrm{hrs}$ \\
\hline Volumetric Loading Rate, VLR & $6.30 \mathrm{~kg}-\mathrm{COD} / \mathrm{m}^{3}-$ day \\
\hline Gas production & $16644 \mathrm{~m}^{3}$ \\
\hline $\mathrm{CH}_{4}$ production & $8654.88 \mathrm{~m}^{3}$ \\
\hline Total sludge production & $3536 \mathrm{~kg} / \mathrm{day}$ \\
\hline
\end{tabular}

Conclusions and Recommendations 


\section{Reactor Design Based on Laboratory Results}

- Therefore, hydraulic retention time based on the observed parameters, $\mathrm{tD}=$ Depth/velocity $=5 / 0.5=10 \mathrm{hrs}$

(Ok! because the optimum observed value is $16 \mathrm{hrs}$ )

- Calculating the volume of the reactor, $\mathrm{V}=\mathrm{tD} \times \mathrm{Q}=10 \mathrm{hrs} \times 210 \mathrm{~m}^{3} / \mathrm{hr}=2100 \mathrm{~m}^{3}$

- Surface area, $\mathrm{A}=\mathrm{V} / \mathrm{H}=2100 / 5=420 \mathrm{~m}^{2}$

- Calculated diameter for the reactor, Dia $=23.13 \mathrm{~m}$, say Dia $=24.0 \mathrm{~m}$

- Actual surface area, $\mathrm{A}=452.16 \mathrm{~m}^{2}$, based on $24.0 \mathrm{~m}$ diameter reactor.

- Actual volume, $\mathrm{V}=2260.80 \mathrm{~m}^{3}$, based on $24.0 \mathrm{~m}$ diameter reactor.

- Check, volumetric loading rate, VLR COD applied $=2.85 \mathrm{~kg} / \mathrm{m}^{3} \times 5000 \mathrm{~m}^{3} /$ day $=14250 \mathrm{~kg} /$ day $\mathrm{VLR}=\mathrm{COD}$ applied $/$ volume of the tank $=14250 / 2260.80=6.30 \mathrm{~kg}-\mathrm{COD} / \mathrm{m}^{3}$-day (Ok! Because the theoretical VLR $=6-20 \mathrm{~kg}-\mathrm{COD} / \mathrm{m}^{3}$-day)

- Optimum COD removal observed $=73 \%$

- Total COD removal $=0.73 \times 14250=10402.50 \mathrm{~kg} /$ day

- Total biogas production $=1.6 \mathrm{~m}^{3} / \mathrm{kg}$-CODrem-d x $10402.50 \mathrm{~kg} /$ day $=16644 \mathrm{~m}^{3}$

- Amount of methane production $=0.62 \times 16644=8654.88 \mathrm{~m}^{3}$

- Amount of sludge produce during the process $=\mathrm{a}+\mathrm{b}+\mathrm{c}$, Where, $\quad \mathrm{a}=(15-18) \%$ BOD removed $\mathrm{b}=(40-50) \%$ of non-biodegradable portion of VSS $\mathrm{c}=\mathrm{TFS}$ $\ldots . .=1476 \mathrm{~kg} /$ day $+1160 \mathrm{~kg} /$ day $+900 \mathrm{~kg} /$ day $=3536 \mathrm{~kg} /$ day

1. Treatment of sugary wastes is technically feasible provided that the $\mathrm{pH}$ of the system is kept near to neutral. This can be achieved by adding $\mathrm{NaHCO}_{3}$ to the feed solution.

2. The volumetric loading rate of $3.0 \mathrm{~kg}-\mathrm{COD} / \mathrm{m}^{3}$-day and an HRT of more than 16 hours are the conservative figures that warrant a removal efficiency of more than $73 \%$; thus, for practical purposes the UASB reactor for sugary wastes could be designed to operate under optimum condition to given acceptable COD removal as per the Pak-EPA limitations.

3. With a reactor of 24.0 meter diameter and 5.0 meter depth, if used for the treatability of sugar mills effluent; an estimated amount of 16,00om 3 of biogas per day could be produced, if the wastewater discharge from the mill is about $21 \mathrm{om}^{3} / \mathrm{hr}$ with COD concentration of $2850 \mathrm{mg} / \mathrm{L}$.

4. Since Pakistan is facing a shortage of energy, encouraging such technologies can help tackle the problem of energy crises.

Based on this study it is recommenced that a comprehensive and long term study is required to study the exact behavior of a UASB reactor for sugary wastes under variable environmental conditions. Moreover, the cost of developing the UASB technology for the larger basis needs to be focused.

Miss Fiza Sarwar has a Masters degree in Environmental Science, and a rich experience in various environmental projects. She is currently working as a faculty member at Bahria University, Islamabad, Pakistan. Corresponding address: fiza_sarwar@yahoo.com

Miss Wajeeha Malik is a professional environmen- talist, graduated from Bahria University, Islamabad. She has obtained a number of academic distinctions, including gold-medal at the graduate level.

Corresponding address: wajeehamalik@live.com

Mr. Muhammad Salman Ahmed is the professional and active environmentalist, graduated from the Bahria University, Islamabad. Presently, serving as a research officer in an international reputed organization.

Corresponding address:mahme2@uis.edu.

Miss Hajra Shahid is a qualified environmental scientist of Bahria University, Islamabad, currently serving as a research associate in a leading multi-national firm.

\section{References}

APHA (American Public Health Association) /AWWA (American Water Works Association) /WEF (Water Environment Federation), 2005, Standard Methods for the examination of water and wastewater (19th ed.), Washington, DC: APHA, AWWA and WEF.

Ali, Arshad, H.N. Hashmi, I.A. Querashi, and Athar Saeed, 2009, Treatment feasibility of NSSC pulping effluent using UASB reactor, HydroNepal: Journal of Water, Energy and Environment 5:57-60.

Ali, Arshad and H.N. Hashmi, 2010, Treatment feasibility of the bleaching effluent obtained from NSSC pulp and paper mill in a UASB reactor, Journal of Engineering and Applied Sciences, 29(3):43-31.

Bhatti, Z.I., 1995, Studies on the Biological Treatment of Methanolic Waste in UASB Reactor, PhD Dissertation, Osaka University, Japan.

Pak-EPA, 1999, Environmental Technology Programme for Industries, Islamabad: Federal Publishers.

Lettinga, G., L.V. Velsen, W.D. Zeeuw, S.W. Hobma and 
A. Klapwijk, 1980, Use of UASB reactor for biological wastewater treatment, especially for anaerobic treatment, Biotechnology and Bioengineering 22:699734 .

Schellinkhout, A., 1993, UASB technology for sewage treatment: experience with a full scale plant and its applicability in Eygpt, Water Science and Technology 27(9):173-180.

Seghezzo, L., G. Zeeman, J. Lier, B. van Hamelers, and
G. Lettinga, 1998, A review: the anaerobic treatment of sewage in UASB and EGSB reactors, Bioresource Technology 65:175-190.

Vieira, S.M.M., 1988, Anaerobic treatment of domestic sewage in Brazil: Research results and full-scale experience, pp.185-196 in E.R. Hall and P.N. Hobson, eds., Proceedings of the Fifth International Symposium on Anaerobic Digestion, Bologna, Italy.

\section{CALENDAR OF EVENTS}

\section{Drinking Water}

21-27 August, 2011: World Water Week, Stockholm, Location: Sweden. More info: http://worldagroforestry. org/projects/searnet/index.php?id=28\&EventID=25.

19-23 September, 2011: First International Sustainable Watershed Management Conference (SuWaMa), Location: Istanbul, Turkey. More info: http://worldagroforestry.org/projects/searnet/index.php?id=28\&EventID=27.

19-21 October, 2011: WaterMed 2011, Location: Milan, Italy. More info: http://www.watermed.com/en_wtm/ index_wtm.asp.

24-25 October, 2011: 2011 OU International Water Conference and Water Prize Award Ceremony, Location: Norman, Oklahoma, USA. More info: http://www.water. ou.edu.

25-27 April, 2012: First International Conference on the Design, Construction, Maintenance, Monitoring and Control of Urban Water Systems, Location: New Forest, United Kingdom. More info: http://www.wessex. ac.uk/12-conferences/urban-water-2012.html.

\section{Energy}

5-7 August, 2011: Fifth International Workshop on Natural Energies (IWONE 2011), Location: Sweden. More info: http://www.iet-community.org/iwone/IWONE5/

12-14 August, 2011: 2011 International Conference on Energy and Electrical Systems (ICEES 2011), Location: Kuala Lumpur, Malaysia. More info: http://www.icees. org/

4-7 September, 2011: 10th International Conference on Sustainable Energy Technologies, Location: Istanbul, Turkey. More info: http://www.set2011.org.

15 September, 2011: International Conference on "Best Practices in Distribution", Location: India. More Info: www.cbip.org.

20-22 September, 2011: Jordan International Energy Conference, Location: Amman, Jordan. More info: http://www.jeaconf.org/jiec2011/index.html.

27-29 September, 2011: Renewable Energy World Asia, Location: Kuala Lumpur, Malaysia. More info: http://www.renewableenergyworld-asia.com.
27-30 September, 2011: 2011 IEEE International Conference on Smart Grid and Clean Energy Technologies (IEEE ICSGCE 2011), Location: Chengdu, China. More info: http://www.icsgce.com/

7-19 October, 2011: World Renewable Energy CongressIndonesia: The International Conference and Exhibition on Renewable Energy and Energy Efficiency, Location: Bali, Indonesia. More info: http://www.wreeec2011bali.com.

12-14 October, 2011: International Conference on Sustainable Development through Renewable Energy Technology, Location: Kathmandu, Nepal. More info: http://www.retrudconference.com/index.php/returd/ retrud2011; Contact: ces@ioe.edu.np

14-17 November, 2011: The 2011 International Conference on Water, Energy, and the Environment, Location: Sharjah, United Arab Emirates. More info: http:// www.aus.edu/conferences/icwes/

15-17 November, 2011: WATEC Israel 2011, The 6th International Exhibition and the 3rd International Conference on Water Technologies, Renewable Energy and Environmental Control, Location: Tel Aviv Exhibition Centre, Tel Aviv, Israel. More info: http// www.watecisrael.com.

16-17 November, 2011: Biofuels International expo and Conference, Location: Antwerp, Belgium. More info: http://www.biofuelsinternationalexpo.com/

20 - 24 November, 2011: 2011 WEC Executive Assembly; Further details to follow; Location: Oran, Algeria. Contact: Deborah Best, Manager, Governance Processes; More info: http://www.worldenergy.org/about_wec/ executive_assembly/oran_2011/default.asp; contact: best@worldenergy.org.

24-26 November, 2011: Electric Power Engineering and Control Systems 2011 (EPECS-2011), Location: Lviv, Ukraine. More info: http://epecs.ukrscience.org/en.

20-22 December, 2011: Third International Renewable Energy Conference, Location: Hammamet, Tunisia. More info: http://www.irec.cmerp.net.

4-6 January, 2012: International Conference on Renewable Energy Utilization (ICREU 2012), Location: Coimbatore, Tamilnadu, India. More info: http://www. icreu2012.com. 